\title{
The Acute Effects of Static and Dynamic Stretching Exercises on Dynamic Balance Performance
}

\section{Statik ve Dinamik Germe Egzersizlerinin Dinamik Denge Üzerine Akut Etkisi}

\author{
Nevzad Denerel1, Metin Ergün², Oğuz Yüksel², Cengizhan Özgürbüz², Oğuz Karamızrak² \\ ${ }^{1}$ Sports Sciences Department, Faculty of Health Sciences, Doğu Akdeniz University, Turkish Republic of Northern Cyprus \\ ${ }^{2}$ Sports Medicine Department, Faculty of Medicine, Ege University, Izmir, Turkey \\ ${ }^{3}$ Sports Medicine Department, Faculty of Medicine, Dokuz Eylül University, Izmir, Turkey
}

\section{N. Denerel \\ 0000-0002-2760-7035 \\ M. Ergün (iD) \\ 0000-0003-0568-6251 \\ 0 . Yüksel (iD) \\ 0000-0003-1834-0444 \\ C. Özgürbüz (iD \\ 0000-0003-0728-4555}

0. Karamızrak

0000-0002-1860-6671

Geliş Tarihi/Date Received: 20.06.2018

Kabul Tarihi/Date Accepted: 12.11.2018

Yayin Tarihi/Published Online: 27.02.2019

Yazışma Adresi /

Corresponding Author:

Nevzad Denerel

Doğu Akdeniz Üniversitesi, Sağlık Bilimleri Fakültesi Spor Bilimleri Bölümü, Mağusa,

Kuzey Kıbrıs Türk

Cumhuriyeti

E-mail: newzatze@yahoo.com

(C2019 Türkiye Spor Hekimleri Derneği. Tüm hakları saklıdır.

\section{ABSTRACT}

Objective: The main purpose of this study was to investigate the acute effects of static and dynamic stretching exercises on dynamic balance.

Materials and Methods: Sixty-seven recreational athletes (33 males aged $20.5 \pm 2.3$ yrs) and 34 females aged $21.4 \pm 3.0 \mathrm{yrs}$ ) were tested in three different protocols including the control condition, static stretching, and dynamic stretching exercises on three separate days, 48-72 $\mathrm{h}$ apart. Before and after each protocol, double limb dynamic balance was tested on an isokinetic balance system. Each protocol involved warm-up for 5 min using the bicycle ergometer at 50-60 rpm and $70 \mathrm{~W}$. Stretching exercises were applied bilaterally on four different lower extremity muscle groups. For the control condition, after warm-up, subjects rested for $12 \mathrm{~min}$ and $45 \mathrm{~s}$. The time period between the two dynamic balance measurements was equal for each protocol.

Results: All three protocols positively affected dynamic balance performance $(p<0.01)$. There was no significant difference between effects of protocols on dynamic balance $(p>0.05)$.

Conclusions: Static stretching after warm-up, dynamic stretching after warm-up, and warm-up alone have positive effect on dynamic balance. Static or dynamic stretching after warm-up do not potentiate positive effect of warm-up alone on dynamic balance.

Keywords: Dynamic balance, static stretching, dynamic stretching, warm-up

\section{ÖZ}

Amaç: Bu çalışmanın temel amacı statik ve dinamik germe egzersizlerinin dinamik denge üzerindeki akut etkilerini araştırmaktı.

Gereç ve Yöntemler: Altmış yedi rekreasyonel sporcu $(20.5 \pm 2.3$ yaşında 33 erkek ve $21.4 \pm 3.0$ yaşında 34 kadın), 48-72 saat arayla üç farklı günde; kontrol grubu, statik germe ve dinamik germe egzersizleri olmak üzere üç farklı egzersiz protokolü ile test edildi. Her egzersiz protokolü öncesi ve sonrasında, izokinetik denge sistemi kullanılarak çift ayak dinamik denge ölçüldü. Her protokole, ısınma olarak 50-60 rpm ile 70 W'da 5 dk süreyle bisiklet ergometresi kullandırıldı. Germe egzersizleri, bilateral olarak dört farklı alt ekstremite kas grubuna uygulandı. Kontrol grubu için, ısınma sonrasında deneklere $12 \mathrm{dk} 45 \mathrm{~s}$ dinlenme süresi verildi. İki dinamik denge ölçümü arasındaki süre, her protokol için eşit olacak şekilde ayarlandı.

Bulgular: Egzersiz protokollerinin üçü de dinamik denge performansını olumlu yönde etkiledi $(p<0.01)$. Egzersiz prokollerinin dinamik denge üzerindeki olumlu etkileri arasında fark bulunmadı ( $p>0.05)$. 
Sonuç: Isınma sonrası statik germe, ısınma sonrası dinamik germe ve sadece ısınma dinamik denge performansını olumlu etkilemektedir. Isınma sonrası yapılan statik germe veya dinamik germe, sadece ısınmanın dinamik denge performansına yaptığı olumlu etkiyi arttırmamaktadır.

Anahtar sözcükler: Dinamik denge, statik germe, dinamik germe, ısınma

Available at: http://journalofsportsmedicine.org and http://dx.doi.org/10.5152/tjsm.2019.127

Cite this article as: Denerel N, Ergün M, Yüksel O, et al. The acute effects of static or dynamic stretching exercises on dynamic balance performance. Turk J Sports Med. 2019;54(3):148-57.

\section{INTRODUCTION}

Although it is generally believed that stretching exercises improve sports performance, it has been argued lately that different stretching exercise protocols prior to sports activity may have different effects on performance (1).

Recent scientific studies were designed to investigate the acute effects of stretching exercises, especially dynamic and static type stretching exercises, on components of performance. There are many studies showing that static stretching has negative impact on sports performance (2-5). However, studies using static stretching lasting shorter than $60 \mathrm{~s}$ report no negative effect on athletic performance $(4,6-11)$. Few studies have argued that static stretching exercises have positive effect on performance $(8,12-14)$. Unlike static stretching exercises, the effect of dynamic stretching exercises on athletic performance is reported to be positive in many studies $(3,5,10$ $12,15)$. Studies reporting negative $(6,14)$ or no effect (16) are limited. Two recent reviews $(1,17)$ stated that the duration of stretching can affect the influence of stretching on athletic performance parameters.

Previous studies about stretching and balance primarily investigated the effects of static stretching on balance and reached arguable results, while just a few investigated the effects of dynamic stretching $(6,18,19)$, and only a single study (6) investigated the role of gender.

In the light of the above, this study was designed to address whether static or dynamic stretching exercises should be preferred prior to sports activity. On this point, we focused on balance. The importance of balance ability in injury prevention is well known, and was studied extensively. However balance ability's effect on athletic performance is less clear (20).
Most of the research investigating the effects of stretching on balance studied dynamic balance $(6,7,9,12,13,18)$ and few studied static balance $(2,19,21)$. Dynamic balance in daily activities and sports activities is necessary for optimum performance (22). Also, poor dynamic balance is an important factor that may increase the risk of injury in athletic participitation (23). Therefore, the main purpose of this study was to investigate the acute effects of both static and dynamic stretching exercises on dynamic balance.

\section{MATERIALS and METHODS}

\section{Experimental Approach}

A self-controlled randomized prospective study design was used to evaluate the acute effects of static and dynamic stretching exercise on dynamic balance performance. Testing consisted of three protocols. The sequence of the three different exercise protocols including static stretching, dynamic stretching, and warm-up alone as a control, was randomly aasigned to avoid potential biasing effects. Before and after each exercise protocol, dynamic balance was tested by using an isokinetic balance system.

\section{Subjects}

A total of 73 (34 male, 39 female) recreational athletes volunteered to take part in this study. Subjects were players of badminton $(n=22: 13$ male, nine female), basketball $(n=23$ : nine male, 14 female), and tennis ( $\mathrm{n}=28: 12$ male, 16 female), with similar characteristics. Detailed training levels and medical histories of all the subjects were established, and physical exams were completed. Inclusion criteria were: to be $18-30$ years of age, to train once or twice a week with a trainer for at least two months. Exclusion criteria were: to have a vestibular, visual, neurological, or musculo- 
skeletal problem that can affect balance; to train more than twice a week, musculoskeletal injury in the last six months, using medication that can impair balance.

Two subjects did not complete all protocols, three subjects had leg length discrepancy, and one subject had a muscle injury while playing basketball during the study. After exclusion of six subjects (a male, five females) a total of 67 (33 males, 34 females) subjects were included in the study. Characteristics of subjects are given in Table 1.

Table 1. Physical charactersitics of the study population

\begin{tabular}{lcc}
\hline & Female (n:34) & Male (n:33) \\
\hline Age $(\mathrm{yrs})$ & $21.4 \pm 3.0$ & $20.5 \pm 2.3$ \\
Height $(\mathrm{cm})$ & $22.7 \pm 3.0$ & $23.0 \pm 3.0$ \\
Body weight $(\mathrm{kg})$ & $163.1 \pm 7.4$ & $177.6 \pm 7.5$ \\
Body mass index $\left(\mathrm{kg} / \mathrm{m}^{2}\right)$ & $60.3 \pm 8.8$ & $72.7 \pm 12.2$ \\
\hline
\end{tabular}

The study design was reviewed for ethics and approved by the Ege University Human Investigations Ethic Committee. Participants were informed about potential risks and benefits of participitation in the study. No injuries occurred during the testing sessions.

\section{Procedures}

Subjects were tested on three different days, 4872 hours apart. They were asked not to use alcohol and to avoid excessive physical activity for $24 \mathrm{~h}$ before testing sessions. Each testing day started with double limb dynamic balance measurement on an isokinetic balance system, which is followed by warm-up, intervention and double limb dynamic balance measurement, respectively. Subjects warmed up for $5 \mathrm{~min}$ on a bicycle ergometer at 50-60 rpm and $70 \mathrm{~W}$. Intervention was static stretching protocole, dynamic stretching protocole or rest (sitting on a chair). All interventions lasted $12 \mathrm{~min}$ and $45 \mathrm{~s}$.

\section{Stretching protocols}

Stretching exercises were applied bilaterally to four different lower extremity muscle groups: knee extensors (quadriceps), knee flexors (hamstring), ankle plantar flexors (gastrocnemius-soleus) and ankle dorsiflexors (tibialis anterior).

Static Stretching Protocol: All static stretches were active and were held at the point of mild discomfort without pain (Figure 1). Each static stretch was repeated three times for $15 \mathrm{~s}$, with a $15 \mathrm{~s}$ rest between each stretch repetition and was repeated on the opposite limb. For the plantar flexors, the $15 \mathrm{~s}$ stretching was split into two, half for gastrocnemius and half for soleus, beginning with the gastrocnemius. 

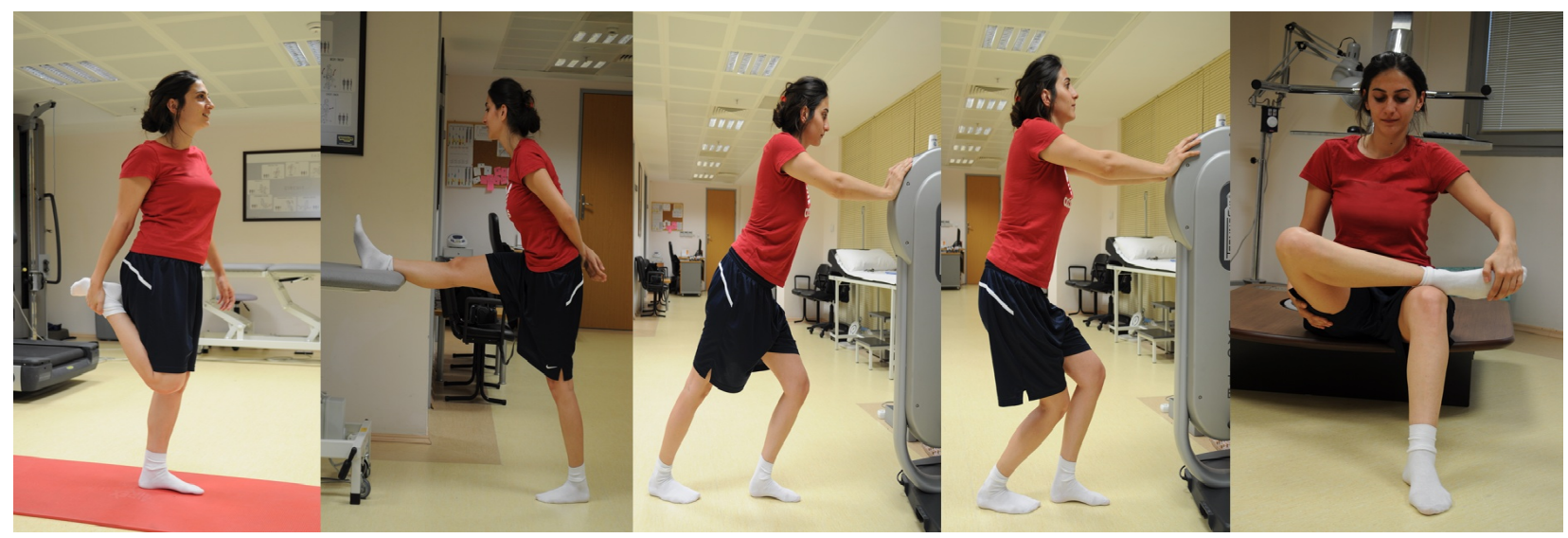

Figure 1. Static stretchings
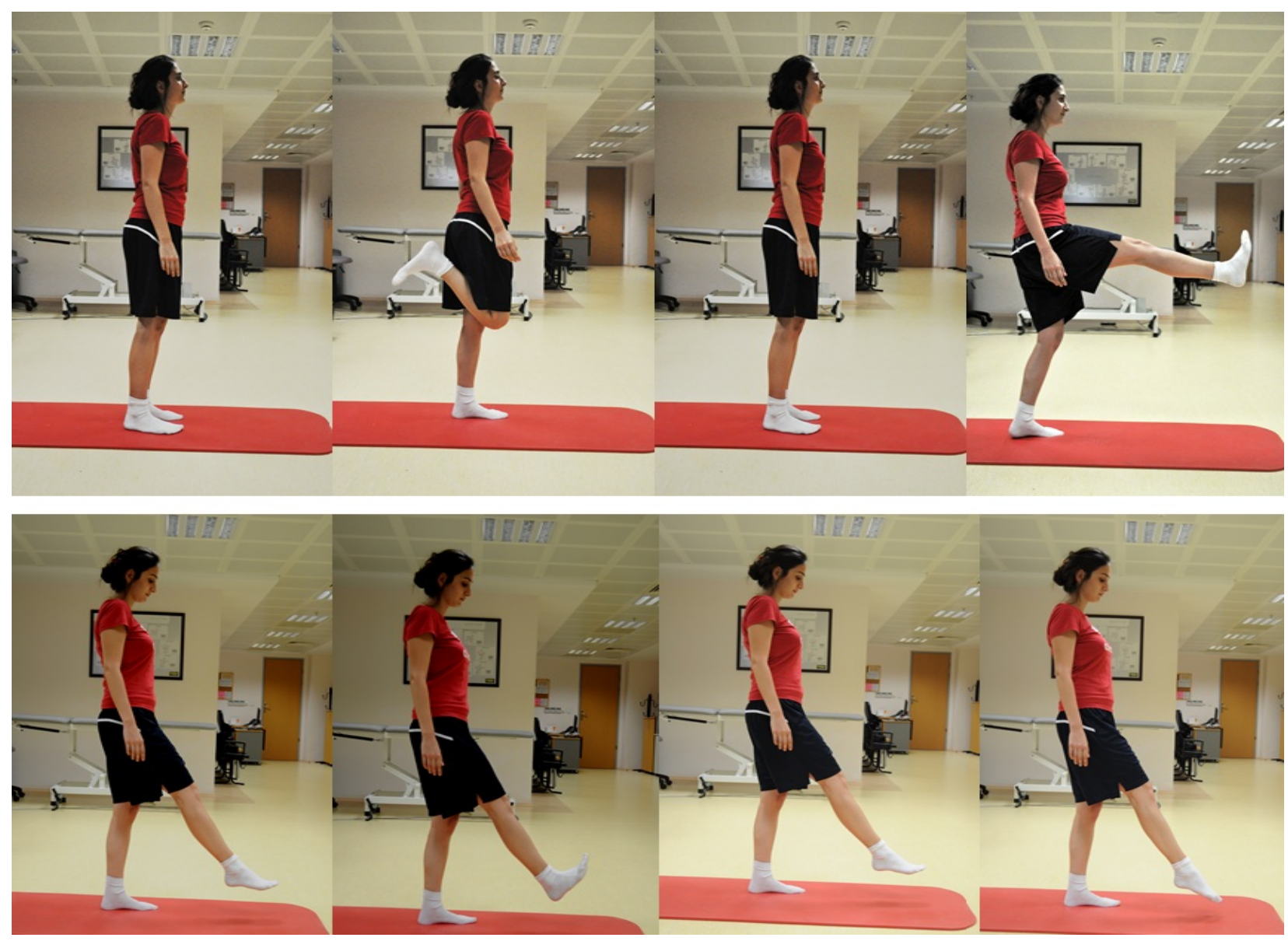

Figure 2. Dynamic stretchings

Quadriceps and hamstring stretching exercises were performed at standing position as described by Şekir et al. (15).

Ankle plantar flexor muscles: In standing position, the subject leans into a solid surface. Foot of the side to be stretched is placed posterior to the other foot while feet are in neutral position, and the subject facing straight to solid surface. The subject leans forward till feeling a mild discomfort in the gastrocnemius muscle while the stretch side knee is straight, and heel is on the ground. 
After keeping this position for $7.5 \mathrm{~s}$, the subject moved stretch side foot forward while flexing the same side knee till feeling discomfort in the soleus muscle, and kept this position for another $7.5 \mathrm{~s}$.

Ankle dorsiflexor muscles: In sitting position, subjects lifted the extremity of the side to be stretched and placed foot of the lifted extremity on the opposite side's knee. While the foot is in neutral position, the subject pulled the anterior part of the foot till feeling a discomfort in tibialis anterior muscle without pain. Pull maneuver was performed carefully to plantar flex the ankle without eversion and inversion (Figure 1).

Dynamic Stretching Protocol: Subjects voluntarily contracted the antagonist of the target muscle in standing upright position and flexed or extended the joints involved once every $2 \mathrm{~s}$ so that the target muscle is stretched (Figure 2). Dynamic stretching in each muscle group was repeated for two sets 15 times (first five times slowly and then the next 10 times as quickly and powerfully as possible, without bouncing). Every dynamic stretching set resumed $30 \mathrm{~s}$, applying $15 \mathrm{~s}$ rest between each stretch repetition.

The order of target muscle and resting periods was the same as those in static stretching, and overall stretching time was the same (11'45") for both dynamic and static stretching protocols.

\section{Balance protocol}

An isokinetic balance system device (PK-252, Tecnobody, Italy) was used, and the "Equilibrium Management Test" program which is reported to be reliable (24) was selected for dynamic balance measurements (Figure 3). This program gives the Total Stability Index (TSI), which is the average index, degree of tilt in all directions horizontally from the center of the platform, during the measurement of dynamic balance. According to Testerman and Vander (25), TSI is the most important indicator revealing a person's ability to balance the platform. Low TSI values indicate better balance.

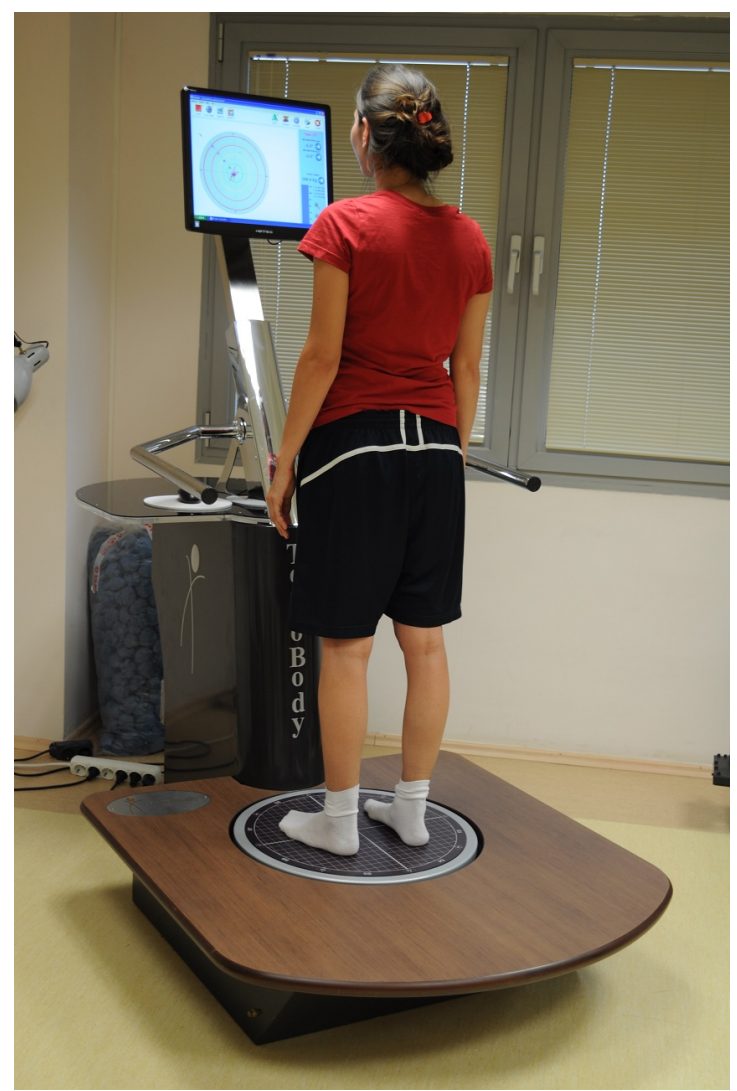

Figure 3. Dynamic balance measurement

In the "Equilibrium Management Test" program, one of the factors that needs to be set in terms of standardization is the "Force Absorber" system. This system determines the freedom of the platform through four pistons placed beneath the platform. Six different resistance options are available as 1-5-10-20-30-40, from most free to most stable. In a similar study investigating dynamic balance of recreational athletes designed by Costa et al. (12), where the resistance of the piston ranged from one to eight, and the third resistor selected. As this study is carried out on recreational athletes, the appropriate piston resistance was selected as 10 .

Placing the feet on the center of the platform is very important for balance measurement, as the reference points that the feet are placed on can alter balance score (26). For this reason, prior to the first dynamic balance measurement, subjects were asked to identify the spot where their feet were at equal distances from the center, and 
parallel to each other; and to find the position that they felt comfortable and well-balanced. Thus, the best position of the feet was marked. These positions were marked through reference points on the disc. Individuals' feet positions were thus at the same reference points during each trial for standardization.

During the test, subjects were asked to try to keep their position as long as possible by standing double-footed and barefoot on a $55 \mathrm{~cm}$ platform. Also, they were asked to keep their hands on the side of their legs, with eyes on the monitor. During the dynamic balance test, if subjects lost balance and contacted the device with their arms, they were immediately asked to try to resume the test.

Measurements of dynamic balance were made before and following the protocols applied. Subjects were allowed three practices before each test attempt to minimize learning effects. Each dynamic balance test lasted $30 \mathrm{~s}$.

The subjects were made to rest for one minute after the application of each protocol; thus, the time period between the two dynamic balance measurements, including the warm-up period, lasted a total of $17^{\prime} 45^{\prime \prime}$ for each exercise protocol.

The same researcher explained all procedures to all subjects and controlled every stage for correct timing and stretching movements.

\section{Statistical analysis}

Statistical results were analyzed using the SPSS program (v15.0). Descriptive statistics, including means and standard deviations were provided for the data. The Shapiro-Wilks test was used for normality analysis. Non-parametric tests were used due to non-normal distribution of data. Mann-Whitney U test was used to examine the differences between genders. The Wilcoxon sum rank test was used to examine effects of interventions on dynamic balance. Friedman test was used to compare effects of different interventions. Covariance analysis was used to adjust TSI scores to stature. Statistical significance was accepted at the level of $\mathrm{p}<0.05$.

\section{RESULTS}

The research revealed that all the three warmup, static, and dynamic stretching protocols positively affect dynamic balance performance $(\mathrm{p}<0.01)$ (Table 2), with no significant difference between either genders ( $p>0.05)$ or protocols ( $p>0.05)$ (Table 3). There was a significant difference in pre-intervention TSI scores between genders $(\mathrm{p}<0.001)$. By adjusting pre-intervention TSI scores to height, mean TSI of males became $1.70 \pm 0.12$ and that of females $1.61 \pm 0.12$ $(\mathrm{p}=0.67)$.

Table 2. The acute effects of each exercise protocol on dynamic balance performance

\begin{tabular}{lcccccc}
\hline & \multicolumn{2}{c}{ Warm-up } & \multicolumn{2}{c}{ Static stretching } & \multicolumn{2}{c}{ Dynamic stretching } \\
\hline & Pre WU TSI & Post WU TSI & Pre SS TSI & Post SS TSI & Pre DS TSI & Post DS TSI \\
Females $(\mathrm{n}=34)$ & $1.58 \pm 0.61$ & $1.30 \pm 0.41^{\dagger}$ & $1.67 \pm 0.72$ & $1.34 \pm 0.47^{\ddagger}$ & $1.76 \pm 0.77$ & $1.30 \pm 0.37^{\ddagger}$ \\
Males $(\mathrm{n}=33)$ & $2.42 \pm 1.41$ & $1.82 \pm 0.95^{\ddagger}$ & $2.40 \pm 1.08$ & $1.85 \pm 0.78^{\ddagger}$ & $2.50 \pm 1.32$ & $2.00 \pm 0.94^{\ddagger}$ \\
Total $(\mathrm{n}=67)$ & $2.00 \pm 1.15$ & $1.56 \pm 0.77^{\ddagger}$ & $2.03 \pm 0.98$ & $1.59 \pm 0.69 \ddagger$ & $2.13 \pm 1.13$ & $1.64 \pm 0.79 \ddagger$ \\
\hline
\end{tabular}

Data as angular degree, mean \pm SD. WU: warm-up, SS: static stretching, DS: dynamic stretching, TSI: total stability index. Significant difference between pre- and post- protocol ( $\uparrow: p<0.005$; $: p<0.0001)$. 
Table 3. Comparison of exercise protocols and genders, concerning the percent improvements in balance score

\begin{tabular}{lcccc}
\hline & $\begin{array}{c}\text { Warm-up } \\
\text { TSI difference (\%) }\end{array}$ & $\begin{array}{c}\text { Static stretching } \\
\text { TSI difference (\%) }\end{array}$ & $\begin{array}{c}\text { Dynamic stretching } \\
\text { TSI difference (\%) }\end{array}$ & p \\
\hline Females $(\mathrm{n}=34)$ & $11.8 \pm 29.1$ & $12.2 \pm 30.7$ & $20.7 \pm 19.7$ & 0.703 \\
Males $(\mathrm{n}=33)$ & $21.4 \pm 19.9$ & $17.8 \pm 25.9$ & $17.3 \pm 21.9$ & 0.391 \\
p & 0.097 & 0.217 & 0.618 & \\
Total $(\mathrm{n}=67)$ & $16.5 \pm 25.3$ & $15.4 \pm 28.4$ & $19.0 \pm 20.7$ & 0.901 \\
\hline
\end{tabular}

Data as percent change in balance score after intervention, mean \pm SD. WU: warm-up, S: static stretching, DS: dynamic stretching, TSI: total stability index.

\section{DISCUSSION}

For dynamic balance performance in the three exercise protocols; considering women, men, and all subjects, a positive and statistically significant effect was present, with no difference between genders. In addition, the three protocols were not found to be superior to each other statistically. Lipshits et al. (27) found that when balance is perturbed, lower extremity muscles were the first to respond. This description makes clear the role and importance of the lower limbs to maintain balance. Therefore, in the present study, four different stretching exercises for lower extremity muscle group were applied to assess the effect of balance in standing, which plays a role in stabilizing the knee and the ankle. Thus, distinct from all related articles, the tibialis anterior muscle was added to the assessment due to its impact on ankle stability control.

Behm et al. (2) investigated the acute effect of static stretching exercises on double foot static balance performance by testing 16 male college students. Stretching sessions involved a $5 \mathrm{~min}$ cycle ergometer warm-up followed by $3 \times 45 \mathrm{~s}$ bilateral static stretching of the quadriceps, hamstrings, gastrocnemius and soleus muscles with a $15 \mathrm{~s}$ rest period for each muscle group.

They stated that static balance performance is positively affected by solely warm-up exercises, and the effect of static stretching is negative. Using the same stretching protocol, Costa et al. (12), with the participation of 28 female recreational athletes, investigated the acute effects of different durations of static stretching exercises on double foot dynamic balance peformance. The research included warm-up exercises as control, $3 \times 15$ " and $3 \times 45$ " static stretching protocols, and concluded that $15^{\prime \prime}$ static stretching had positive effects, whereas 45 " static stretching or solely warm-up exercises had no effect on dynamic balance performance.

A study by Handrakis et al. (13) investigated the effects of static stretching on balance and tested Soo Bahk Doo (Korean traditional martial arts) athletes consisting of six men and four women 40-60 years of age. Two protocols were applied to all subjects, involving single foot dynamic balance measurement following either $10 \mathrm{~min}$ rest or $3 \times 30$ " static stretching to the lower extremity muscle groups for a total of $10 \mathrm{~min}$. They reported that 30 " lasting static stretching exercises had a statistically greater impact on dynamic balance performance. In contrast to this study, Lewis et al. (7) reported that static stretching of lower extremity muscles $\left(3 \times 45^{\prime \prime}\right)$ had no effect on dynamic balance. It should be noted that study designs in these two studies are different from those of Costa et al. (12), Behm et al. (2), and Kim et al. (9), as they only compared static stretching with resting and did not assess the acute effects of stretching, which can be done by comparing pre- and post-balance test results.

Above mentioned studies $(2,9,12)$ are similar to ours in that balance was measured before and after the stretching protocol; therefore, concerning the acute effect of static stretching on dynamic balance, they should be preferred in comparing results. Thus, the effect of static stretching on dynamic balance performance was found to be compatible with the 15 " static stretching protocol 
findings of Costa et al. (12). Studies investigating longer static stretching times reported no benefits on balance. Kim et al. (9) stated that static stretching (2x45") has no effect on dynamic balance and Behm et al. (2) reported that static stretching $(3 \times 45 ")$ negatively affects static balance.

Ghaffarinejad et al. (28) found that 30" static stretching has beneficial effects on joint position sense and emphasized that it resulted from the increase in proprioceptive feedback. Costa et al. (12) commented that this improvement in proprioception could be the mechanism that is responsible for the positive effects on balance. Mechanisms underlying the effect of stretching on balance are not fully understood. More studies should focus on these mechanisms.

To our knowledge, there are only three studies in current literature investigating the effects of dynamic stretching on balance $(6,18,19)$. They all used a warm-up sesion before stretching. One of them measured balance before and after the stretching protocol (6), which is similar to our methodology, whereas the others measured only following stretching. Thus, Morrin and Redding (19) recruited 10 trained female dancers and compared the acute effects of dynamic stretching $(1 \times 60 ")$, static stretching $\left(2 \times 30^{\prime \prime}\right)$, nonstretching ( 8 min rest after warm-up), and combined (static \& dynamic) protocols on static balance. They used a ballet-spesific warm-up session before interventions and tested balance only after the interventions. They reported that non-stretching, static stretching, and dynamic stretching did not have significant superiority to each other, consistent with our findings.

Chatzopoulos et al. (18), with the participation of 31 female high school athletes, compared the acute effects of dynamic stretching, static stretching (1x30"), and non-stretching (7 min rest after warm-up) on dynamic balance. They stated that dynamic stretching and no stretching protocols have superiority to static stretching. No explanation of this inconsistancy with our findings can be done, as they used a shorter time static stretching then ours. Belkhiria et al. (6) compared the acute effects of three different volumes ( $4 \times 15 ", 8 \times 15^{\prime \prime}$ and $\left.12 \times 15 "\right)$ of dynamic stretching and static stretching on single foot dynamic balance on 28 healthy trained athletes. They found small improvements in star excursion balance test (SEBT) performance with warm-up alone, and stated that there was no substatial effect of adding dynamic or static stretching. Although they remarked that SEBT, which is used to evaluate dynamic balance, may not be the most predictive or appropriate balance test, their findings are compatible with our results.

Two relatively recent reviews discussed the appropriate static stretching duration for optimum performance $(1,17)$. Kay et al. (1) concluded that static stretches totaling shorter than 45 " do not decrease power, strength and speed performance. A total of 45" of static stretch for each muscle in the present study affected dynamic balance performance of recreational athletes positively. Behm and Chaouachi's (17) conclusion was different, as they indicated that static stretching for each individual muscle should be less than 30 " in duration, especially for highly trained athletes.

The present study has revealed that there is no difference between genders, concerning the effect of different stretching exercises on dynamic balance performance, which diverges from the gender difference speculations of Costa et al. (12), who examined only females. Although in the unique study investigating the effect of gender on balance (7) it was hypothesized that stretching may have different effects on balance among genders, as there are gender-based viscoelastic property differences in tendon structures (29) and muscle architecture (30), they found no significant effect of gender on balance, consistent with our findings.

Another important result of this study is that statistically significant improvements of dynamic balance scores in the control group (solely warm-up) were determined. There were no significant changes in Costa et al. (12) study's control group, whereas Behm et al. (2)'s results were similar to ours in this instance. This can be explained with warm-up exercises that increase nerve conduction speed $(31,32)$, and thus the speed of response, which is considered to be perturbed balance (2). McHugh and Cosgrave 
(33) point out that it is important to reach a sufficient range of motion for good athletic performance, and that the warm-up period often provides these, whether it is done with or without stretching exercises. In the study by Wilkins et al. (34), no warm-up exercise was done after the first balance measurement in the controls; they were then tested again after resting for $20 \mathrm{~min}$, and a statistically significant improvement was obtained. They associated it with the effect of learning and pretest practices. Young and Elliott (35) stated that the positive effects of warming up can result in a decrease of negative effects that may occur with stretching exercises. They also stated that warm-up exercises can cause fatigue, which can reduce performance, and reported that warm-up exercises should be avoided in future studies looking at the effects of stretching on performance.

All three exercise protocols in this study included warm-up exercises, and the results revealed that each protocol influenced dynamic balance performance positively. On this point, although Beckenkamp and Lin (36) stated that the effects of warm-up on physical performance are not clear, it can be said that the positive effects of warm-up exercises may in fact be masking the real effects of the different types of stretching. Therefore, future studies are needed to clarify the effect of different stretching exercises on balance by omitting warm-up from the stretching exercise protocols. Studies should also be designed solely with warm-up exercises and a control group that would just rest for the time between pre- and post-test to yield more reliable results.

A limitation of the study is worth considering. Although the order of the procedures was randomized and each subject had three trials before testing, we can not rule out a potential learning effect. Planning an information and trial session about stretching and the balance test system a few days before testing could reduce the potential learning effect by giving the subjects the chance to get used to stretching and balance protocols.

\section{CONCLUSIONS}

Dynamic or static stretching after warm-up and solely warm-up positively affect dynamic balance performance, with no significant superiority to each other in this respect. Consideration of stretching protocols without warm-up seems to be a better strategy in future research focusing on the acute effects of stretching exercises on dynamic balance performance.

\section{REFERENCES}

1. Kay AD, Blazevich AJ. Effect of acute static stretch on maximal muscle performance: a systematic review. Med Sci Sports Exerc. 2012;44(1):154-64.

2. Behm DG, Bambury A, Cahill F, et al. Effect of acute stretching on force, balance, reaction time, and movement time. Med Sci Sports Exerc. 2004;36(8):1397-402.

3. Hough PA, Ross EZ, Howatson G. Effects of dynamic and static stretching on vertical jump performance and electromyographic activity. J Strength Cond Res. 2009;23(2): 507-12.

4. Knudson D, Bennett K, Corn R, et al. Acute effects of stretching are not evident in the kinematics of the vertical jump. J Strength Cond Res. 2011;15(1):98-101.

5. Kokkonen J, Nelson AG, Kornwell A. Acute stretching exercises inhibit maximal strength performance. Res $Q$ Exerc Sport. 1998;69(4):411-5.

6. Belkhiria-Turki L, Chaouachi A, Turki 0, et al. Greater volumes of static and dynamic stretching within a warmup do not impair star excursion balance performance. J Sports Med Phys Fitness. 2014;54(3):279-88.

7. Lewis NL, Brismée JM, James CR, et al. The effect of stretching on muscle responses and postural sway responses during computerized dynamic posturography in women and men. Arch Phys Med Rehabil. 2009;90(3): 454-62.

8. Little T, Williams AG. Effect of differential stretching protocols during warm-ups on high-speed motor capacities in professional soccer players. J Strength Cond Res. 2006;20(1):203-7.

9. Kim K, Lee T, Kang G, et al. The effects of diverse warmup exercises on balance. J Phys Ther Sci. 2014;26(10): 1601-3.

10. McMillian DJ, Moore JH, Halter BS, et al. Dynamic vs. static-stretching warm-up: the effect on power and agility performance. J Strength Cond Res. 2006;20(9):492-9.

11. Yamaguchi $\mathrm{T}$, Ishii K. Effects of static stretching for 30 seconds and dynamic stretching on leg extension power. J Strength Cond Res. 2005;19(3):677-83.

12. Costa PB, Graves BS, Whitehurst M, et al. The acute effects of different durations of static stretching on dynamic balance performance. J Strength Cond Res. 2009;23(1):141-7.

13. Handrakis JP, Southhard VN, Abreu JM, et al. Static stretching does not impair performance in active middle aged adults. J Strength Cond Res. 2010;24(3):825-30. 
14. Torres EM, Kraemer WJ, Vingren JL, et al. Effects of stretching on upper body muscular performance. $J$ Strength Cond Res. 2008;22(4):1279-85.

15. Sekir U, Arabaci R, Akova B, et al. Acute effects of static and dynamic stretching on leg flexor and extensor isokinetic strength in elite women athletes. Scand J Med Sci Sports. 2010;20(2):268-81.

16. Herda TJ, Cramer JT, Ryan ED, et al. Acute effects of static versus dynamic stretching on isometric peak torque, electromyography, and mechanomyography of the biceps femoris muscle. J Strength Cond Res. 2008;22(3):809-17.

17. Behm DG, Chaouachi A. A review of the acute effects of static and dynamic stretching on performance. Eur J Appl Physiol. 2011;111(11):2633-51.

18. Chatzopoulos D, Galazoulas C, Patikas D, et al. Acute effects of static and dynamic stretching on balance, agility, reaction time and movement time. J Sports Sci Med. 2014;13(2):403-9.

19. Morrin N, Redding E. Acute effects of warm-up stretch protocols on balance, vertical jump height, and range of motion in dancers. J Dance Med Sci. 2013;17(1):34-40.

20. Hrysomallis C. Balance ability and athletic performance. Sports Med. 2011;41(3):221-32.

21. Nagano A, Yoshioka S, Hay DC, et al. Influence of vision and static stretch of the calf muscles on postural sway during quiet standing. Hum Mov Sci. 2006;25(3):422-34.

22. Cote KP, Brunet ME, Gansneder BM, et al. Effects of pronated and supinated foot postures on static and dynamic postural stability. J Athl Train.2005;40(1):41-6.

23. Plisky PJ, Rauh MJ, Kaminski TW, et al. Star Excursion Balance Test as a predictor of lower extremity injury in high school basketball players. J Orthop Sports Phys Ther. 2006;36(12):911-9.

24. Paterno MV, Myer GD, Ford KR, et al. Neuromuscular training improves single-limb stability in young female athletes. J Orthop Sports Phys Ther. 2004;34(6):305-16.

25. Testerman C, Vander Griend R. Evaluation of ankle instability using the Biodex Stability System. Foot Ankle Int. 1999;20(5):317-21.
26. Schmitz R, Arnold B. Intertester and intratester reliability of a dynamic balance protocol using the Biodex System. J Sport Rehabil. 1998;7(2):95-101.

27. Lipshits MI, Mauritz K, Popov KE. Quantitative analysis of anticipatory postural components of a complex voluntary movement. Hum Physiol. 1981;7(3):165-73.

28. Ghaffarinejad F, Taghizadeh S, Mohammadi F. Effect of static stretching of muscles surrounding the knee on knee joint position sense. Br J Sports Med. 2007;41(10): 684-7.

29. Kubo K, Kanehisa H, Fukunaga T. Gender differneces in the viscoelastic properties of tendon structures. Eur J Appl Physiol. 2003;88(6):520-6.

30. Kubo K, Kanehisa H, Azuma K, et al. Muscle architectural characteristics in young and elderley men and women. Int J Sports Med. 2003;24(2):125-30.

31. Safran MR, Garrett WE Jr, Seaber AV, et al. The role of warmup in muscular injury prevention. Am J Sports Med. 1988;16(2):123-9.

32. Shellock FG, Prentice WE. Warming-up and stretching for improved physical performance and prevention of sports-related injuries. Sports Med. 1985;2(4):267-78.

33. McHugh MP, Cosgrave $\mathrm{CH}$. To stretch or not to stretch: the role of stretching in injury prevention and performance. Scand J Med Sci Sports. 2010;20(2):169-81.

34. Wilkins JC, Valovich Mcleod TC, Perin DH, et al. Performance on the balance error scoring system decreases after fatigue. J Athl Train. 2004;39(2):156-61.

35. Young W, Elliott S. Acute effects of static stretching, proprioceptive neuromuscular facilitation stretching, and maximum voluntary contractions on explosive force production and jumping performance. Res $Q$ Exerc Sport. 2001;72(3):273-9.

36. Beckenkamp PR, Lin CC. The effects of warm-up on physical performance are not clear. Br J Sports Med. 2011;45(6):525-6. 